\title{
Horizon Scanning to Predict and Prioritize Invasive Alien Species With the Potential to Threaten Human Health and Economies on Cyprus
}

\section{OPEN ACCESS \\ Edited by: Ana Sofia Vaz, \\ University of Granada, Spain \\ Reviewed by: \\ Michaela Roberts, \\ The James Hutton Institute, \\ United Kingdom \\ Bernd Lenzner, \\ University of Vienna, Austria \\ *Correspondence: \\ Jodey M. Peyton \\ joyt@ceh.ac.uk}

Specialty section: This article was submitted to Biogeography and Macroecology, a section of the journal Frontiers in Ecology and Evolution

Received: 27 May 2020 Accepted: 12 August 2020 Published: 21 October 2020

Citation:

Peyton JM, Martinou AF, Adriaens T, Chartosia N, Karachle PK,

Rabitsch W, Tricarico E,

Arianoutsou M, Bacher S, Bazos I,

Brundu G, Bruno-McClung E,

Charalambidou I, Demetriou M,

Galanidi M, Galil B, Guillem R,

Hadjiafxentis K, Hadjioannou $L$,

Hadjistylli M, Hall-Spencer JM, Jimenez C, Johnstone G, Kleitou P,

Kletou D, Koukkoularidou D,

Leontiou S, Maczey N, Michailidis N,

Mountford JO, Papatheodoulou A,

Pescott OL, Phanis C, Preda C,

Rorke S, Shaw R, Solarz W,

Taylor CD, Trajanovski S, Tziortzis I,

Tzirkalli E, Uludag A, Vimercati G, Zdraveski K, Zenetos A and Roy HE (2020) Horizon Scanning to Predict and Prioritize Invasive Alien Species With the Potential to Threaten Human

Health and Economies on Cyprus.

Front. Ecol. Evol. 8:566281.

doi: 10.3389/fevo.2020.566281
Jodey M. Peyton ${ }^{*+}$, Angeliki F. Martinou ${ }^{2,3,4 t}$, Tim Adriaens ${ }^{5+}$, Niki Chartosia ${ }^{6}$, Paraskevi K. Karachle ${ }^{7 t}$, Wolfgang Rabitsch ${ }^{8}$, Elena Tricarico ${ }^{9 t}$, Margarita Arianoutsou ${ }^{10}$, Sven Bacher ${ }^{11+}$, loannis Bazos ${ }^{10 \dagger}$, Giuseppe Brundu ${ }^{12 \dagger}$, Elizabeth Bruno-McClung ${ }^{2}$, Iris Charalambidou ${ }^{13 t}$, Monica Demetriou ${ }^{6}$, Marika Galanidi ${ }^{14+}$, Bella Galil'15, Rhian Guillem ${ }^{16}$, Kypros Hadjiafxentis ${ }^{17}$, Louis Hadjioannou ${ }^{4 t}$, Margarita Hadjistylli ${ }^{18 t}$, Jason Michael Hall-Spencer ${ }^{19 \dagger}$, Carlos Jimenez ${ }^{4 \dagger}$, Graham Johnstone ${ }^{20}$, Periklis Kleitou ${ }^{19,21 t}$, Demetris Kletou ${ }^{21 \dagger}$, Despina Koukkoularidou17, Stalo Leontiou ${ }^{22}$, Norbert Maczey ${ }^{23}$, Nikolas Michailidis ${ }^{24}$, John Owen Mountford ${ }^{1}$, Athina Papatheodoulou ${ }^{25}$, Oliver L. Pescott ${ }^{1+}$, Constantinos Phanis ${ }^{26}$, Cristina Preda ${ }^{27 t}$, Steph Rorke ${ }^{1}$, Richard Shaw ${ }^{23 \dagger}$, Wojciech Solarz ${ }^{28}$, Chris D. Taylor' ${ }^{2}$ Saso Trajanovski29t, lakovos Tziortzis ${ }^{30+}$, Elli Tzirkalli22,31t, Ahmet Uludag ${ }^{32+}$, Giovanni Vimercati11t, Konstantin Zdraveski ${ }^{33 \dagger}$, Argyro Zenetos ${ }^{7+}$ and Helen E. Roy ${ }^{1+}$

'UK Centre for Ecology \& Hydrology, Wallingford, United Kingdom, ${ }^{2}$ Joint Services Health Unit Cyprus, RAF Akrotiri, United Kingdom, ${ }^{3}$ The Cyprus Institute, Nicosia, Cyprus, ${ }^{4}$ Enalia Physis Environmental Research Centre, Lefkosia, Cyprus, ${ }^{5}$ Wildlife Management and Invasive Species, Research Institute for Nature and Forest (INBO), Brussels, Belgium, ${ }^{6}$ Department of Biological Sciences, University of Cyprus, Nicosia, Cyprus, ${ }^{7}$ Hellenic Centre for Marine Research, Institute of Marine Biological Resources and Inland Waters, Anavyssos, Greece, ${ }^{8}$ Environment Agency Austria, Vienna, Austria, ${ }^{9}$ Department of Biology, University of Florence, Sesto Fiorentino, Italy, ${ }^{10}$ Department of Ecology and Systematics, Faculty of Biology, National and Kapodistrian University of Athens, Athens, Greece, ${ }^{11}$ Department of Biology, University of Fribourg, Fribourg, Switzerland, ${ }^{12}$ Department of Agriculture, University of Sassari, Sassari, Italy, ${ }^{13}$ Department of Life and Health Sciences, School of Sciences and Engineering, University of Nicosia, Nicosia, Cyprus, ${ }^{14}$ Ustun Energy Engineering LLC, Marine Ecology Division, Izmir, Turkey, ${ }^{15}$ The Steinhardt Museum of Natural History, Tel Aviv University, Tel Aviv, Israel, ${ }^{16}$ Gibraltar Botanic Gardens, The Alameda, Gibraltar, Gibraltar, ${ }^{17}$ Department of Agriculture, Louki Akrita, Nicosia, Cyprus, ${ }^{18}$ Department of Environment, Lefkosia, Cyprus, ${ }^{19}$ Marine Biology and Ecology Research Centre, University of Plymouth, Plymouth, United Kingdom, ${ }^{20}$ Sovereign Base Area Administration, Environmental Department, Episkopi, United Kingdom, ${ }^{21}$ Marine and Environmental Research (MER) Lab Ltd, Limassol, Cyprus, ${ }^{22}$ School of Pure and Applied Sciences, Open University of Cyprus, Nicosia, Cyprus, ${ }^{23}$ Cabi, Egham, United Kingdom, ${ }^{24}$ Department of Fisheries and Marine Research, Ministry of Agriculture, Rural Development and Environment, Nicosia, Cyprus, ${ }^{25}$ I.A.CO Environmental \& Water Consultants, Nicosia, Cyprus, ${ }^{26}$ Cyprus Ministry of Education, Culture, Sport and Youth, Nicosia, Cyprus, ${ }^{27}$ Department of Natural Sciences, Ovidius University of Constanta, Constanta, Romania, ${ }^{28}$ Institute of Nature Conservation, Polish Academy of Sciences, Kraków, Poland, ${ }^{29}$ Hydrobiological Institute Ohrid, Ohrid, Macedonia, ${ }^{30}$ Water Development Department, Ministry of Agriculture, Rural Development and Environment, Nicosia, Cyprus, ${ }^{31}$ Department of Biological Applications and Technologies, University of Ioannina, Ioannina, Greece, ${ }^{32}$ Department of Plant Protection, Faculty of Agriculture, Çanakkale Onsekiz Mart University, Çanakkale, Turkey, ${ }^{33}$ PI Galicica National Park, Ohrid, Macedonia

Invasive alien species (IAS) are known to be a major threat to biodiversity and ecosystem function and there is increasing evidence of their impacts on human health and economies globally. We undertook horizon scanning using expert-elicitation to predict arrivals of IAS that could have adverse human health or economic impacts on the island of Cyprus. Three hundred and twenty five IAS comprising 89 plants, 37 freshwater animals, 61 terrestrial invertebrates, 93 terrestrial vertebrates, and 45 marine species, were assessed during a two-day workshop involving 39 participants to derive two ranked lists: (1) IAS with potential human health impacts (20 species ranked within 
two bands: 1-10 species or 11-20 species); and, (2) IAS with potential economic impacts (50 species ranked in three bands of 1-10, 11-20, and 21-50). Five species of mosquitoes (Aedes aegypti, Aedes albopictus, Aedes flavopictus, Aedes japonicus, and Culex quinquefasciatus) were considered a potential threat to both human health and economies. It was evident that the IAS identified through this process could potentially arrive through many pathways ( 25 and 23 pathways were noted for the top 20 IAS on the human health and economic impact lists respectively). The Convention on Biological Diversity Level II (subcategory) pathways Contaminant on plants, pet/aquarium/terrarium species (including live food for such species), hitchhikers in or on aeroplanes, hitchhikers in or on ship/boats, and vehicles were the main pathways that arose across both lists. We discuss the potential of horizon scanning lists to inform biosecurity policies and communication around IAS, highlighting the importance of increasing understanding amongst all stakeholders, including the public, to reduce the risks associated with predicted IAS arrivals.

\section{Keywords: prevention, non-native species, negative impact, environmental management, introduction pathways,} communication

\section{INTRODUCTION}

Invasive alien species (IAS), species introduced either intentionally or unintentionally by humans outside of their native range, and causing negative impacts to biodiversity, ecosystem services, economy and/or society, are a major concern globally (Russell et al., 2017; Pauchard et al., 2018; Díaz et al., 2019; Stoett et al., 2019). There is growing evidence of adverse effects of IAS on ecosystem function (Schindler et al., 2015; Vilà and Hulme, 2017), ecosystem services (such as crop production, timber provision, seafood and recreation) and to economies and human health (Schindler et al., 2015; Martinou and Roy, 2018).

Invasive alien species can have direct negative impacts on human health through disease transmission, for example certain mosquito species (Moore and Mitchell, 1997), or through having highly allergenic pollen as is the case with some plants (Samson et al., 2017; Lazzaro et al., 2018). There are also examples of poisonous or venomous marine IAS causing direct health impacts, e.g., the venomous striped eel catfish Plotosus lineatus was responsible for $10 \%$ of the marine organismrelated injuries experienced by fishermen off the coast of Israel (Gweta et al., 2008). Additionally, IAS can have indirect health impacts, for example, loss of agricultural production and food security, or increased traffic accidents (Schindler et al., 2015). Economically, costs of direct impacts and management of IAS to agriculture, forestry and fisheries were estimated at $€ 12.5$ billion in Europe in 2009, but this was considered a conservative estimate (Kettunen et al., 2009). In Great Britain, the cost to the economy incurred by IAS was estimated at $£ 1.7$ billion in 2010 (Williams et al., 2010).

Predicting the arrival of IAS and using this information to prioritize preventative action is therefore often seen as critical for informing the biosecurity and management of such species (Shine et al., 2010; Caffrey et al., 2014; Roy et al., 2015; Booy et al., 2017; Carboneras et al., 2018), with the ultimate goal of reducing the risk and impacts of IAS. Such prioritized lists of potential IAS provide an important tool to guide monitoring and inform early-warning detection systems, preventative action and biosecurity, as well as focusing the communication of risk to all stakeholders, including the public. Pathway action plans, which consider the ways IAS are transported around the world (Hulme et al., 2008), look to mitigate the risk of introduction through different pathways (Convention on Biological Diversity [CBD], 2014; Harrower et al., 2018), and are one approach to managing biological invasions informed by prioritized lists (Key and Moore, 2019).

Here, we present the outcomes of a horizon scanning study using an expert-elicitation approach (Roy et al., 2020), previously used in Great Britain (Roy et al., 2014), Europe (Roy et al., 2019a) and the United Kingdom Overseas Territories (Roy et al., 2019b). We build on a previous study in which a priority list of IAS with the potential to threaten biodiversity and ecosystems (Peyton et al., 2019) was derived for Cyprus through expert elicitation (Roy et al., 2020). We extend this approach to predict marine, terrestrial, and freshwater IAS which have the potential to threaten human health and economies for the island of Cyprus, including the Sovereign Base Areas of Akrotiri and Dhekelia.

\section{MATERIALS AND METHODS}

\section{Study Area}

Cyprus, located in the eastern Mediterranean, is the third largest island in the region and is bordered by Asia to the north and east, Europe to the west, and Africa to the south. The Mediterranean basin is renowned for being a biodiversity hotspot (Myers et al., 2000), and Cyprus has a high level of endemism across different taxonomic groups (Sparrow and John, 2016). Cyprus hosts a diverse range of habitats, from winter snow-capped mountains, conifer forest (containing species such as the endemic cedar Cedrus brevifolia), and coastal cliffs, to saltmarsh, riverine and agricultural plains. Other members of the European Union are the most important trading partner of Cyprus, with goods imported primarily from Greece, United Kingdom, Italy, and Germany 
(Ministry of Energy, Commerce, Industry, and Tourism, 2014). In addition to strong trade links across Europe, it is estimated that over $€ 2.23$ billion revenue was generated from tourism for the period of January to September 2019 (Statistical Service of the Republic of Cyprus, 2019). Potatoes, wine, citrus are among products exported from Cyprus and are important both economically and culturally. These key trade and tourism activities are important when considering potential pathways of introduction for IAS.

\section{Selection of Experts}

The experts involved in this horizon scanning study represented a range of disciplines with experience in biological invasions, human health and social economics (see Supplementary Information 1 for the full list of participants). Forty-five experts contributed to the listing and initial scoring of the species. Most of the experts had more than 5 years' experience of working on IAS but two early career researchers studying biological invasions and conservation also contributed. All the thematic group leaders had previously participated in at least one horizon scanning study. Twenty-four of the 45 experts that contributed to the species listing in the current workshop had also contributed to a previous horizon scanning study on Cyprus (Peyton et al., 2019). The number of experts within each group varied from eight to thirteen. The plant species (terrestrial and freshwater) were scored by eight people, freshwater animals (invertebrates and fish) by seven people, terrestrial invertebrates by nine people, terrestrial vertebrates by eight people and marine species (invertebrates, vertebrates, and primary producers) by 13 people. Two experts from the terrestrial invertebrates group also worked within the plants group but only scored species for the terrestrial invertebrate group. Mosquitoes were included within the freshwater animals group. Thirty-nine of the 45 experts were present at the workshop.

To ensure clarity, the approach was clearly outlined through a guidance document (Supplementary Information 2) circulated six weeks before the workshop and through a presentation at the beginning of the workshop.

\section{Data Sources}

Consultation on proposed IAS was undertaken between experts through e-mail discussions in advance of the workshop and through the workshop breakout groups. The long-list of IAS derived from the 2017 horizon scan of Peyton et al. (2019) for IAS to impact Cypriot biodiversity and ecosystem services was used as a starting point from which the thematic groups further updated, modified and developed the lists through consultation of relevant databases (e.g., CABI compendium and horizon scanning tool, GBIF, GRIIS, CyDAS) and other sources including peer-reviewed and gray literature of IAS with known invasion history around the world. Additionally, IAS of note from a recent study prioritizing IAS for the UKOTs were also considered during this initial selection (Roy et al., 2019b).

\section{Excluded IAS}

Thirty-eight IAS from the Peyton et al. (2019) biodiversity and ecosystem list of 225 IAS were not considered relevant to the process outlined here: four plants, four freshwater animals, eight terrestrial invertebrates, seven terrestrial vertebrates, 13 marine animals and two marine plants. For the plant IAS that were removed, several were described for Cyprus subsequent to the 2017 workshop, although they may have arrived and established in Cyprus prior to 2017, e.g., Heliotropium currasavicum (Charilaou, 2018) and small-leaf spiderwort Tradescantia fluminensis (Spitale and Papatheodoulou, 2019). The four freshwater IAS (two mosquitofish fish Gambusia spp.), Nile tilapia Oreochromis niloticus, and two crustaceans: Louisiana crayfish Procambarus clarkii (Department of Environment, 2019; Ueda, 2020) and the tadpole shrimp Triops cancriformis (Tziortzis et al., 2014) were not considered because they were already established in Cyprus. Terrestrial invertebrates that were not considered, were omitted because there was recently published evidence of their presence on Cyprus, e.g., the three ants, the fire ant Solenopsis geminata, the pharoah ant Monomorium pharaonis and Pheidole indica (Salata et al., 2017). Terrestrial vertebrates were either not considered because they were established, e.g., brown rat Rattus norvegicus (Psaroulaki et al., 2006), or not relevant because of the absence of active pathways, e.g., Canadian beaver Castor canadensis and American mink Neovison vison. Wild boar Sus scrofa was added to the list as there had been past (1990s) releases for hunting in Cyprus, but populations were subsequently eradicated (Hadjisterkotis and Heise-Pavlov, 2006). The marine IAS list was considerably reduced as: (a) three IAS were reported from the island since 2017 (killer algae Caulerpa taxifolia var. distichophylla, the bryozoan Amathia verticillata and common moon crab Matuta victor); (b) one IAS (white crust tunicate Didemnum perlucidum) is cryptogenic (a species that cannot be reliably demonstrated as being either introduced or native, Carlton, 1996) and hence removed; and, (c), for the remaining eleven IAS the likelihood of arrival (mainly through shipping) and establishment was re-evaluated as low, and hence removed.

\section{Scoring IAS}

Experts were asked to score each potential IAS within their thematic group for their separate likelihoods of: (i) arrival, (ii) establishment, (iii) magnitude of the potential negative impact on human health or economies. Quantification of the impact score on human health and economy were performed using a scoring scheme modified from the SEICAT system (Bacher et al., 2018) as shown in Table 1. Only primary impacts were considered; for example, should a person be absent from work because they were ill from a mosquito-borne infection, this would only be considered within human health impacts, but not economic impact.

We scored likelihood of arrival, establishment and impact (either human health or economic) for each IAS on a 5point scale $(1=$ low likelihood; $5=$ high likelihood $)$ such that the maximum score, the product of the three scores, possible was 125. IAS scored were present on both the human health and economy lists with scores given for each impact category. For all the IAS included within the priority lists, we documented the pathways using the Convention on Biological Diversity (CBD) Level II (subcategory) nomenclature 
TABLE 1 | Magnitude of impacts of invasive alien species on human health and economy adapted from Bacher et al. (2018).

\begin{tabular}{|c|c|c|c|}
\hline Score of impact & Magnitude of impact & Impact on human health & Impact on Economy \\
\hline 1 & Minimal & $\begin{array}{l}\text { No deleterious impacts or local, short-term reversible } \\
\text { effects to few individuals }\end{array}$ & $\begin{array}{l}\text { No deleterious impacts reported (not being confused } \\
\text { with "data deficient") }\end{array}$ \\
\hline 2 & Minor & $\begin{array}{l}\text { Local, short-term reversible effects to larger groups of } \\
\text { people }\end{array}$ & $\begin{array}{l}\text { Negative effect on agriculture such that the alien taxon } \\
\text { makes it difficult for individuals to participate in their } \\
\text { normal activities, e.g., via income loss, higher effort or } \\
\text { expenses to participate in activities. Activities are still } \\
\text { carried out, i.e., the number of people participating in } \\
\text { that activity remains the same }\end{array}$ \\
\hline 3 & Moderate & $\begin{array}{l}\text { Local, but irreversible effects on small groups of people } \\
\text { or reversible effects on larger groups of people }\end{array}$ & $\begin{array}{l}\text { Negative effects leading to changes in activities, i.e., the } \\
\text { number of people participating decreases, but the } \\
\text { activity is still carried out }\end{array}$ \\
\hline 4 & Major & $\begin{array}{l}\text { Local, significant irreversible effects at the regional scale } \\
\text { or reversible effects over large areas }\end{array}$ & $\begin{array}{l}\text { Local disappearance of the activity from all or part of } \\
\text { the area invaded. Likely to be reversible within a decade } \\
\text { after removal or control of the alien taxon. The } \\
\text { disappearance refers to the typical spatial scale over } \\
\text { which practices in the region are characterized }\end{array}$ \\
\hline 5 & Massive & $\begin{array}{l}\text { Widespread, severe, long-term, irreversible health } \\
\text { effects over large areas }\end{array}$ & $\begin{array}{l}\text { Local disappearance of the activity from all or part of the } \\
\text { area invaded. Likely to be permanent and irreversible } \\
\text { for at least a decade after removal of the alien taxon, } \\
\text { due to fundamental structural changes of conditions }\end{array}$ \\
\hline
\end{tabular}

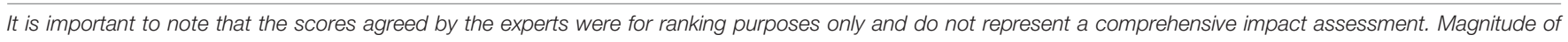

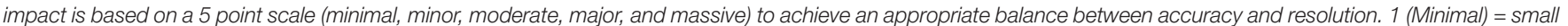

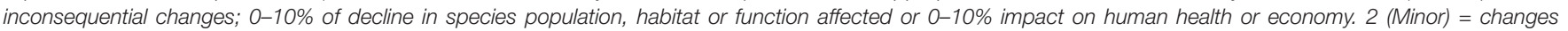

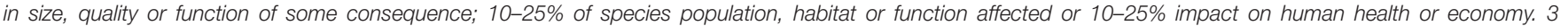

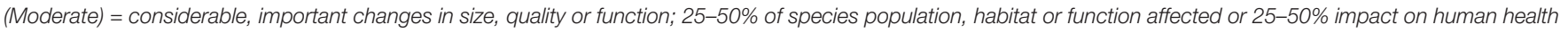

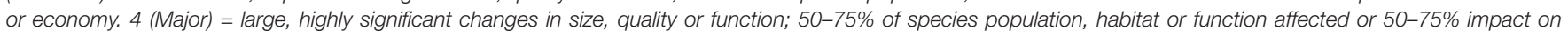

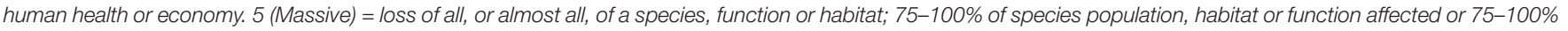
impact on human health or economy.

(Convention on Biological Diversity, 2014; Harrower et al., 2018), by which they are considered most likely to arrive. The temporal scope for the predictions, was of IAS likely to arrive in the next 10 years.

The geographic scope of the search for potential IAS was global but with the following restrictions. IAS were only considered:

(i) If currently absent from Cyprus. Farmed animals such as goats Capra hircus were considered to be already established in the wild and, therefore, the potential for feral invasive populations was not considered here.

(ii) If there was documented invasion histories illustrating undesirable impacts in previously invaded regions.

(iii) If pathways of introduction of the IAS are active, that is:

(a) The IAS are traded within Cyprus or are present in areas that have strong trade or travel connections with Cyprus, and there is a recognized potential pathway of introduction.

(b) The IAS are present in captivity including in gardens, zoological parks, private collections, pet shops, aquaculture facilities or greenhouses.

\section{Ranking the Species by Consensus}

The workshop (27-29 November 2019) considered the potential human health and economic impacts of a list of IAS following the methods outlined in Peyton et al. (2019) based on Roy et al. (2019b). In order to reduce potential bias that can occur with any expert-elicitation process (Sutherland and Burgman, 2015), we followed the ten guiding principles outlined in Roy et al. (2020). The IAS identified and scored by the experts within the thematic groups were compiled to produce a long list which was ordered on the basis of the scores given for each IAS. All the experts met in plenary to discuss the IAS and rank them within bands to provide a prioritized list. The overall scores a species received were only used as a guide to help inform the expertelicitation process. Categorization of species into different bands allowed for greater resolution of prioritization which can then be linked to priority of management or awareness raising. The overall scores a species received were used a guide to help inform the expert-elicitation process.

\section{RESULTS}

A total of 325 IAS were compiled into a long-list for consideration during the human health and economic impacts workshop. These 325 consisted of 89 plants, 37 freshwater animals, 61 terrestrial invertebrates, 93 terrestrial vertebrates and 45 marine species. Two prioritized IAS lists were derived: human health and economy.

The group, in plenary, reached a consensus on the ranking of 20 IAS predicted to have the potential for human health impacts in bands of 1-10 and 11-20 (Table 2). In contrast, 50 IAS with the potential for economic impacts was agreed through consensus in bands of 1-10, 11-20, and 21-50 (Table 3). The difference in list length reflects the higher number of 
IAS considered a significant risk to economies compared to the number of IAS considered a human health threat. Supplementary Information 3 gives the full list of 325 IAS reviewed during the workshop.

Ten freshwater animals, five of which were mosquitoes (yellow fever mosquito Aedes aegypti, Asian tiger mosquito Ae. albopictus, Ae. flavopictus, Asian bush mosquito Ae. japonicus and southern house mosquito Culex quinquefasciatus) comprised half of the species in the human health list. Five plants, four marine species and a terrestrial vertebrate constituted the remaining species in the human health top 20 list. There were no terrestrial invertebrates present within the human health top 20 list (Figure 1).

Within the ranked economic impact list, the numbers of IAS within each thematic group were more evenly divided, with five plant species, five freshwater animal species, four terrestrial invertebrate species, four terrestrial vertebrate species, and two marine species represented (Figure 1). The IAS ranked from 21 to 50 within the list of IAS constituting a potential threat to economies within Cyprus included 13 invasive alien plant species, six marine IAS, five terrestrial invertebrates and terrestrial vertebrates and a single freshwater animal (Table 3).

Ten of the IAS were considered a potential threat to both human health and economies. These ten IAS comprised five species of mosquito (Ae. aegypti, Ae. albopictus, Ae. flavopictus, Ae. japonicus and C. quinquefasciatus), three plant IAS (ragweed Ambrosia artemisiifolia, Cape ivy Delairea odorata and whitetop weed Parthenium hysterophorus) and two marine IAS (white stinger Macrorhynchia philippina and P. lineatus).

Twenty-five CBD Level II (subcategories) were identified for the top 20 IAS for human health and 23 pathways identified for the top 20 IAS for economy [Figure 2; all CBD Level I and II (subcategory) pathway names are given in italics]. The CBD Level II pathways, Contaminant on plants, pet/aquarium/terrarium species (including live food for such species), hitchhikers in or on aeroplanes, hitchhikers in or on ship/boats and vehicles were the main introduction pathways that arose across both the list of IAS with potential human health and economic impacts.

For plants and freshwater animals, 14 separate introduction pathways were identified, for terrestrial animals seven were identified, five for terrestrial vertebrates and six for marine IAS (Figure 3). Marine, freshwater animals, terrestrial invertebrates and plants were considered more likely to be introduced via Transport pathways, both as contaminants or stowaways, whereas terrestrial vertebrates were considered more likely to be introduced through Release or Escape pathways. For marine IAS, Corridor - interconnected waterways/basins/seas, namely the Suez Canal, was noted as an important pathway.

\section{DISCUSSION}

Prioritizing IAS that are currently absent within a region but could arrive, is an important component of IAS management, with clear ecological and economic benefits (Caffrey et al., 2014; Roy et al., 2015; Booy et al., 2017). The lists of IAS predicted to arrive, establish, and have adverse effects on human health and/or economies derived through this horizon scanning study complement the list derived in 2017 for IAS predicted to impact biodiversity and ecosystems (Peyton et al., 2019). The 325 IAS identified span a diverse range of taxa, habitats and ecosystems.

\section{High Scoring IAS}

The list of IAS predicted to have human health impacts was dominated by mosquitoes. Mosquitoes are considered to be the most important vectors of disease (Romi et al., 2018). The invasion of the Asian tiger mosquito Ae. albopictus, a competent vector of disease, in the Mediterranean is facilitated by climate change (Roiz et al., 2011). Ryan et al. (2019) show shifts in Aedes-borne virus distributions toward the poles under changing climate as habitat suitability changes for both Ae. aegypti and Ae. albopictus. Ae. albopictus has caused outbreaks of chikungunya fever in Italy (Rezza et al., 2007; Riccardo et al., 2019). France, Croatia and Spain have reported autochthonous (i.e., locally acquired) cases of dengue fever linked to established Ae. albopictus populations (Succo et al., 2016; ECDC, 2019) and the risk of introduction of Ae. albopictus to Cyprus is a major concern. In addition to the risk of disease transmission, mosquitoes can also be considered a nuisance and can affect human well-being. They can deter visitors from recreational spaces, which in turn causes adverse economic impacts (Medlock and Vaux, 2015; Martinou et al., 2020). Recognizing the paucity of knowledge on invasive diseases (Roy et al., 2017), we excluded pathogens and other disease causing agents other than those transmitted by invasive alien vectors, such as mosquitoes. However, it was noted that the ongoing spread of the plant pathogenic bacterium Xylella fastidiosa in the Mediterranean region was seen as of major concern and a threat for the economy of Cyprus. Bosso et al. (2016) show that although climate change is unlikely to increase the climatic suitability range of $X$. fastidiosa in the Mediterranean, it strongly supports phytosanitary measures around the spread of this bacterium as there are many countries with prevailing suitable conditions, including Cyprus. The bacterium causes serious diseases in a wide range of plants, including olive trees, and is transmitted by various different Hemiptera species. Although it is a European and Mediterranean Plant Protection Organization (EPPO) quarantine organism, and measures are in place, its arrival on Cyprus would have be detrimental to the economy (Saponari et al., 2019).

\section{IAS Policy}

Regulation (EU) No 1143/2014 on the prevention and management of the introduction and spread of invasive alien species (the 'IAS Regulation') requires European Union Member States to identify and prioritize pathways of unintentional introduction and spread of IAS of Union concern. Ranked lists are also valuable for the development of action plans to tackle priority pathways of introduction and spread. Five IAS of Union concern occurred within the two top 20 lists: water-hyacinth Eichornia crassipes; P. hysterophorus; P. lineatus; raccoon Procyon 
TABLE 2 | Invasive alien species (IAS) considered to have high likelihood of arrival, establishment and human health impacts within Cyprus and ranked within two bands: top 1-10 IAS and 11-20 IAS.

\begin{tabular}{|c|c|c|c|c|c|c|c|c|c|c|}
\hline Rank & Species & Common name & Thematic group & & & & athways & & & \\
\hline $1-10$ & Aedes albopictus & Tiger mosquito & Freshwater animals & Air & Ship & Veh & Con Plant & & & \\
\hline $1-10$ & Plotosus lineatus* & Striped eel catfish & Marine & Water & Nat & Pet & Res & & & \\
\hline $1-10$ & Parthenium hysterophorus & Whitetop weed & Plants & Lug & Seed & Mach & THM & & & \\
\hline $1-10$ & Culex quinquefasciatus & Southern house mosquito & Freshwater animals & Ship & Air & & & & & \\
\hline $1-10$ & Ambrosia artemisiifolia & Common or annual ragweed & Plants & Other Transport & Lug & Nat & Seed & THM & Veh & Mach \\
\hline $1-10$ & Macrorhynchia philippina* & White stinger & Marine & Hull & Nat & & & & & \\
\hline $1-10$ & Procyon lotor & Raccoon & Terrestrial vertebrates & BZA & Other Escape & Pet & & & & \\
\hline $1-10$ & Aedes aegypti & Yellow fever mosquito & Freshwater animals & Air & Ship & Veh & Con Plant & & & \\
\hline $1-10$ & Aedes flavopictus & A mosquito & Freshwater animals & Air & Ship & Veh & Con Plant & & & \\
\hline $1-10$ & Aedes japonicus & East Asian bush mosquito, rock pool mosquito & Freshwater animals & Air & Ship & Veh & Con Plant & & & \\
\hline $11-20$ & Broussonetia papyrifera & Paper mulberry & Plants & Orn & For & Nat & EC & & & \\
\hline $11-20$ & Synanceia verrucosa* & Reef stonefish & Marine & Water & & & & & & \\
\hline $11-20$ & Pomacea canaliculata & Golden apple snail & Freshwater animals & $\mathrm{R}$ & $\mathrm{Aq}$ & Pet & Bait & Con Plant & THM & Ang \\
\hline $11-20$ & Pomacea maculata & Giant apple snail & Freshwater animals & $\mathrm{R}$ & $\mathrm{Aq}$ & Pet & Bait & Con Plant & THM & Ang \\
\hline $11-20$ & Sinanodonta woodiana & Chinese giant mussel & Freshwater animals & Food & & & & & & \\
\hline $11-20$ & Phyllorhiza punctata* & Spotted jellyfish & Marine & Hull & Ballast & Water & Nat & & & \\
\hline $11-20$ & Datura wrightii & Sacred datura & Plants & Seed & & & & & & \\
\hline $11-20$ & Dreissena rostriformis bugensis & Quagga mussel & Freshwater animals & Ballast & Hull & & & & & \\
\hline $11-20$ & Delairea odorata & Cape Ivy or German Ivy & Plants & Orn & CNM & & & & & \\
\hline $11-20$ & Limnoperna fortunei & Golden mussel & Freshwater animals & Ballast & Hull & & & & & \\
\hline
\end{tabular}

For each species the common name alongside the thematic group is given. Additionally the most likely pathways of arrival are also included. The pathway subcategory terminology follows Convention on Biological Diversity [CBD] (2014) and Harrower et al. (2018). Numbers in brackets alongside the pathway descriptions = occurrences within the table. EC, Erosion control (1); R, Release in nature for use (2); Ag, Agriculture (1); Aq, Aquaculture (2); BZA, Botanical garden/zoo/aquaria (1); Pet, Pet/aquarium/terrarium species (4); For, Forestry (1); Orn, Ornamental purpose other than horticulture (2); Res, Research and ex situ breeding (in facilities) (1); Other, Other escape from confinement (1); CNM, Contaminant nursery material (1); Bait, Contaminated bait (2); Food, Food contaminant (1); Con Plant, Contaminant on plants (excluding parasites and species transported by host and vector) (4); Seed, Seed contaminant (3); THM, Transportation of habitat material (2); Air, Hitchhikers in or on airplane (5); Ship, Hitchhikers in or on a ship/boat (5); Mach, machinery/equipment (2); Lug, People and their luggage/equipment (2); Ballast, Ship/boat ballast water (3); Hull, Ship/boat hull fouling (4): Veh, Vehicles (5); Other Transport, Other means of transport (1); Water, Interconnected waterways/basins/seas (3); Nat, Natural dispersal across borders of invasive alien species that have been introduced (5). Species marked with an asterisk (*) are marine species that the "waterway" pathway refers to introduction through the Suez Canal. 
TABLE 3 | Invasive alien species (IAS) considered to have high likelihood of arrival, establishment and economic impacts within Cyprus and ranked within three bands: top 1-10 IAS, 11-20 IAS, and 21-50 IAS

\begin{tabular}{|c|c|c|c|c|c|c|c|c|c|c|}
\hline Rank & Species & Common name & Thematic group & & & Pathn & ays & & & \\
\hline $1-10$ & Daktulosphaira vitifoliae & Grapevine phylloxera & Terrestrial invertebrates & CNM & Con Plant & & & & & \\
\hline $1-10$ & Parthenium hysterophorus & Whitetop weed & Plants & Lug & Seed & Mach & THM & & & \\
\hline $1-10$ & Eichhornia crassipes & Water hyacinth & Plants & Hort & Ang & Orn & & & & \\
\hline $1-10$ & Aedes albopictus & Tiger mosquito & Freshwater animals & Air & Veh & Con plant & Ship & & & \\
\hline $1-10$ & Culex quinquefasciatus & Southern house mosquito & Freshwater animals & Air & Ship & & & & & \\
\hline $1-10$ & Ambrosia artemisiifolia & Common or annual ragweed & Plants & Other Transport & Lug & Nat & Seed & THM & Veh & Mach \\
\hline $1-10$ & Anoplophora chinensis & Citrus longhorn beetle & Terrestrial invertebrates & $\pi$ & Con Plant & Container & Ship & & & \\
\hline $1-10$ & Leptinotarsa decemlineata & Colorado potato Beetle & Terrestrial invertebrates & CNM & Con Plant & THM & Container & Air & Ship & \\
\hline $1-10$ & Plotosus lineatus* & Striped eel catfish & Marine & Water & Nat & Res & Pet & & & \\
\hline $1-10$ & Sus scrofa & Wild boar & Terrestrial vertebrates & $\mathrm{H}$ & & & & & & \\
\hline $11-20$ & Psittacula krameri & Ring-necked parakeet & Terrestrial vertebrates & Pet & & & & & & \\
\hline $11-20$ & Pycnonotus jocosus & Red-whiskered bulbul & Terrestrial vertebrates & Pet & Other Escape & & & & & \\
\hline $11-20$ & Anoplophora glabripennis & Asian longhorn beetle & Terrestrial invertebrates & $\pi$ & Con Plant & Container & Ship & & & \\
\hline $11-20$ & Senecio inaequidens & Narrow-leaved ragwort & Plants & Con Anim & Seed & Veh & Mach & & & \\
\hline $11-20$ & Aedes aegypti & Yellow fever mosquito & Freshwater animals & Air & Veh & Con plant & Ship & & & \\
\hline $11-20$ & Aedes flavopictus & A mosquito & Freshwater animals & Air & Veh & Con plant & Ship & & & \\
\hline $11-20$ & Aedes japonicas & East Asian bush mosquito, rock pool mosquito & Freshwater animals & Air & Veh & Con plant & Ship & & & \\
\hline $11-20$ & Delairea odorata & Cape Ivy or German Ivy & Plants & Orn & CNM & & & & & \\
\hline $11-20$ & Callosciurus erythraeus & Pallas's squirrel & Terrestrial vertebrates & Pet & Other Escape & Nat & BZA & & & \\
\hline $11-20$ & Macrorhynchia philippina* & White stinger & Marine & Hull & Nat & & & & & \\
\hline $21-50$ & Sphagneticola trilobata & Wedelia & Plants & Hort & THM & L & Orn & Other Escape & & \\
\hline $21-50$ & Penaeus aztecus & Northern brown shrimp & Marine & $\mathrm{Aq}$ & & & & & & \\
\hline $21-50$ & Procyon lotor & Raccoon & Terrestrial vertebrates & BZA & Other Escape & Pet & & & & \\
\hline $21-50$ & Prosopis juliflora & Prosopis & Plants & For & Hort & $\mathrm{L}$ & Orn & & & \\
\hline $21-50$ & Salvinia molesta & Giant salvinia & Plants & Pet & BZA & Orn & Ang & Water & CNM & \\
\hline $21-50$ & Decapterus russelli* & Indian scad & Marine & Water & Nat & & & & & \\
\hline $21-50$ & Phyllorhiza punctata* & Spotted Jellyfish & Marine & Hull & Ballast & Water & Nat & & & \\
\hline $21-50$ & Myiopsitta monachus & Monk parakeet & Terrestrial vertebrates & Pet & & & & & & \\
\hline $21-50$ & Rattus exulans & Pacific rat & Terrestrial vertebrates & Ship & & & & & & \\
\hline $21-50$ & Myriophyllum aquaticum & Brazilian water milfoil & Plants & Pet & Ang & Orn & & & & \\
\hline $21-50$ & Pistia stratiotes & Water cabbage & Plants & Hort & Pet & Orn & L & & & \\
\hline $21-50$ & Verbesina encelioides & Golden crownbeard & Plants & Mach & Veh & Seed & Con Anim & & & \\
\hline $21-50$ & Araujia sericifera & Bladderflower & Plants & Orn & BZA & Mach & Lug & Veh & & \\
\hline $21-50$ & Tamarix ramosissima & Salt cedar or pink tamarisk & Plants & EC & L & Orn & & & & \\
\hline $21-50$ & Synanceia verrucosa* & Reef stonefish & Marine & Water & & & & & & \\
\hline $21-50$ & Cotylorhiza erythraea* & Jellyfish & Marine & Water & & & & & & \\
\hline $21-50$ & Marivagia stellata* & Jellyfish & Marine & Water & & & & & & \\
\hline $21-50$ & Phenacoccus peruvianus & Bougainvillea mealybug & Terrestrial invertebrates & Con Plant & & & & & & \\
\hline $21-50$ & Dreissena rostriformis bugensis & Quagga mussel & Freshwater animals & Nat & & & & & & \\
\hline $21-50$ & Mustela putorius furo & Ferret & Terrestrial vertebrates & Other Escape & $\mathrm{BC}$ & $\mathrm{H}$ & & & & \\
\hline
\end{tabular}




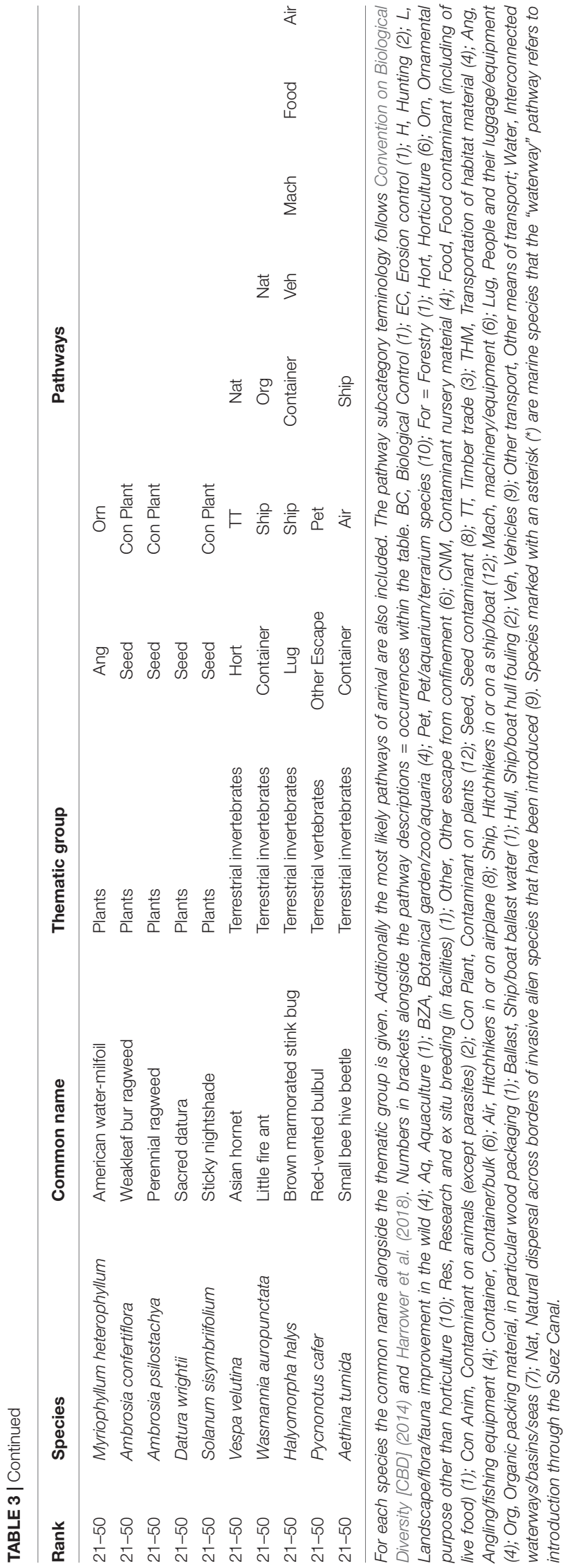

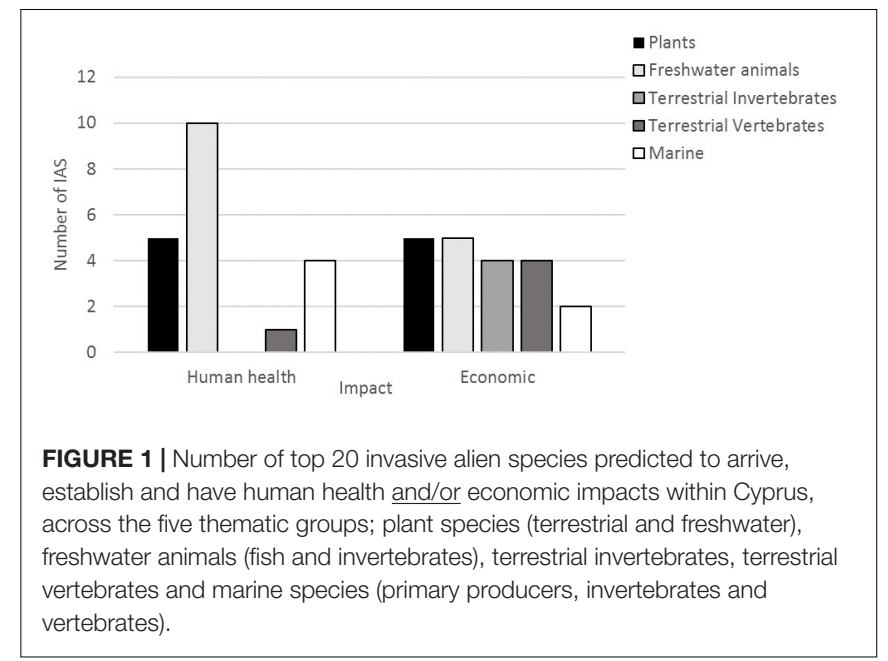

lotor and Asian hornet Vespa velutina. There is one EPPO A1 species citrus longhorn beetle Anoplophora glabripennis (A1 species are absent from the EPPO region) and three EPPO A2 species Eichhornia crassipes, grapevine phylloxera Daktulosphaira vitifoliae, and Colorado potato beetle Leptinotarsa decemlineata (A2 species are locally present in the EPPO region) on our list. Cyprus also has a protected zone status for D. vitifoliae, L. decemlineata and the bark beetle Ips sexdentatus under the EU Plant Health Law [Regulation (EU) 2016/2031 \& (EU) 2019/2072]. Ips sexdentatus was present on the longer list of IAS that were reviewed, but with moderate scores for chance of arrival and establishment (Supplementary Information 3), and hence not present within our ranked lists. Daktulosphaira vitifoliae and $L$. decemlineata occur on our priority list for economic impact. As such, measures are needed to avoid the introduction of these pests (e.g., restrictions on movement of commodities, surveys) and to ensure their eradication if found present. We anticipate that the lists of IAS identified through this horizon scanning will have relevance for Cyprus but also more widely across the region. Indeed, the inclusion of experts with expertise in policy and roles within the Cypriot government departments was seen as critical to ensure relevance of the expert-elicitation process. The Department of the Environment within the Cyprus Government outlines activities in relation to EU Commitments through Regulations and Directives including the IAS Regulation and the Habitats Directive in their Strategic Plan ${ }^{1}$. The need to raise awareness and inform different stakeholders through the establishment of programs and voluntary agreements are seen as critical for the implementation of relevant environmental actions and measures.

\section{Awareness Raising Including Case Studies for Five IAS}

Five species, one from each of the thematic groups to provide representative examples for a range of taxa and environments, were selected from the top 20 human health and economic impact

\footnotetext{
${ }^{1}$ http://www.moa.gov.cy/moa/environment/environmentnew.nsf/index_en/ index_en?OpenDocument
} 


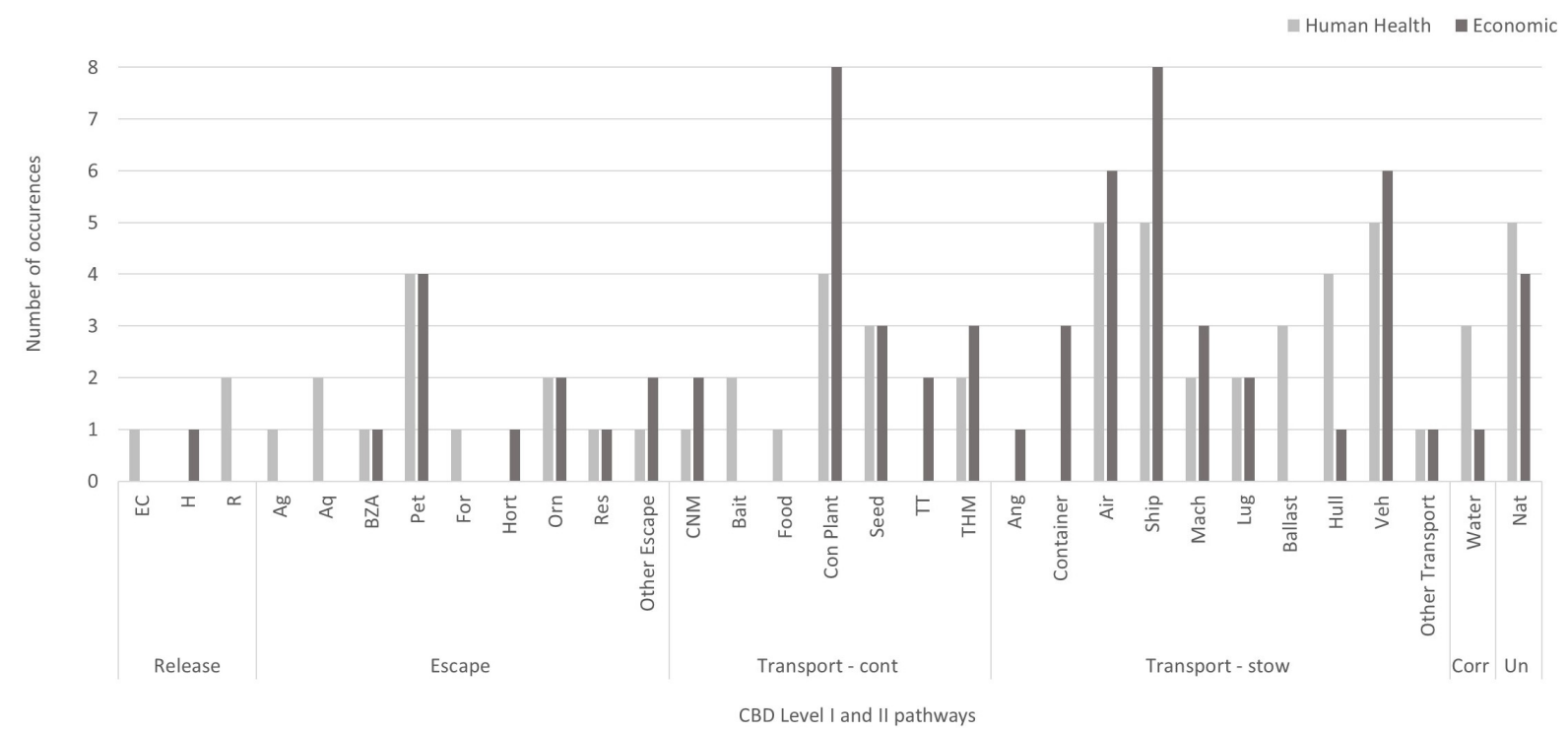

FIGURE 2 | Number of occurrences of CBD Level I and II (subcategory) pathways of arrival (Convention on Biological Diversity, 2014; Harrower et al., 2018) for the top 20 invasive alien species predicted to arrive, establish and have human health and/or economic impacts within Cyprus. CBD Level I pathways are given first, followed by CBD Level II pathways. Release in nature (Release): EC, Erosion control; H, Hunting, R, Release in nature for use. Escape from confinement (Escape): Ag, Agriculture (including Biofuel feedstocks); Aq, Aquaculture; BZA, Botanical garden/zoo/aquaria; Pet, Pet/aquarium/terrarium species; For, Forestry; Hort, Horticulture; Orn, Ornamental purpose other than horticulture; Res, Research and ex situ breeding (in facilities); Other Escape, Other escape from confinement. Transport - contaminant (Transport - cont): CNM, Contaminant nursery material; Bait, Contaminated bait; Food, Food contaminant; Con Plant, Contaminant on plants; Seed - Seed contaminant; TT, Timber Trade; THM, Transportation of habitat material. Transport - stowaway (Transport - stow): Ang, Angling/fishing equipment; Container, Container/bulk; Air, Hitchhikers on airplane; Ship, Hitchhikers on a ship/boat; Mach, machinery/equipment; Lug, People and their luggage/equipment; Ballast, Ship/boat ballast water; Hull, Ship/boat hull fouling; Veh, Vehicles; Other Transport, Other means of transport. Corridor: Water, Interconnected waterways. Unaided: Nat, Natural dispersal across borders of invasive alien species that have been introduced.

lists, for further discussion in the paper. We highlight where developing communication campaigns around their pathways of introduction could raise awareness of the threat these IAS pose to human health and economies across Cyprus. Raising awareness of the impacts of IAS is, and will continue to be, an important part of the management of the introduction, spread and impact of species that cause negative impacts (Booy et al., 2017). When communicating information on IAS, it is important to use clear messaging from the project onset and throughout the duration of programs (Davis et al., 2018). Campaigns such as the "Check, Clean, Dry," designed to communicate information and so decrease the spread of freshwater IAS have been widely implemented (Defra, 2010). Public perception of management options can be counter to the requirement to control IAS (Hine et al., 2015; Novoa et al., 2017; Crowley et al., 2019; Shackleton et al., 2019), and so it is critical to include stakeholders, including the public, in the development of communication campaigns, to develop shared understanding of the challenges posed by IAS. There are a number of Europe-wide initiatives including the COST Action Alien $\mathrm{CSI}^{2}$ which will be informative for the development of communication campaigns to raise awareness about the IAS identified through this study.

Increased awareness would be beneficial for informing prevention and early-warning strategies across all IAS, however it is likely that campaigns targeted at specific IAS or, indeed, specific

${ }^{2}$ https://alien-csi.eu/ relevant sectors and stakeholders will be most effective (Davis et al., 2018). Here we provide representative examples of the IAS prioritized within the top 20 in one or both of the lists (human health and economic impacts), highlighting the breadth of taxa, environments and introduction pathways (Figure 4). CBD Level I and II (subcategory) pathways (Convention on Biological Diversity, 2014; Harrower et al., 2018) are used throughout in italics when describing pathways of introduction.

\section{Parthenium hysterophorus Whitetop Weed}

Parthenium hysterophorus, a plant originally from Mexico, Central and South America (ISSG, 2010), was ranked in the top 20 in both the human health and economic impacts lists. Parthenium hysterophorus, an IAS of Union concern, has had large impacts on human health where it causes breathing difficulties and allergenic reactions in humans (Patel, 2011). It can kill cattle and contaminate meat and milk, reducing the quality (Lakshmi and Srinivas, 2007), and so also has economic impacts (McConnachie et al., 2011). Notably it is present in Israel which has similar climatic conditions to Cyprus. At the time of the workshop, there were 28 direct flights per week between Cyprus and Israel. This IAS was predicted to arrive through luggage/equipment (in particular tourism), as a seed contaminant, on machinery/equipment and through transportation of habitat material (soil, vegetation, wood etc.); 

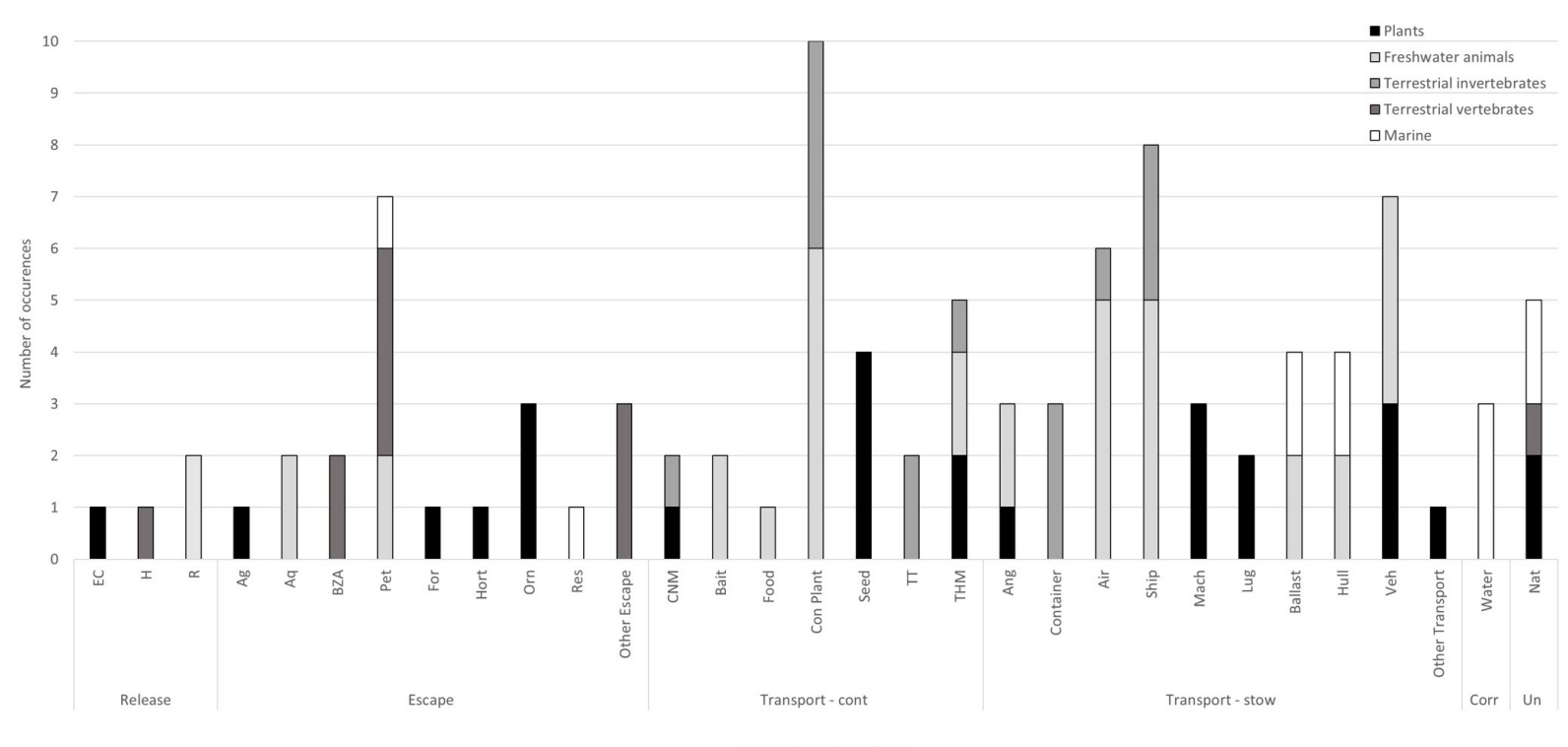

CBD Level I and II pathways

FIGURE 3 | Number of occurrences of CBD Level I and II (subcategory) pathways of arrival (Convention on Biological Diversity [CBD], 2014; Harrower et al., 2018) for the top 20 invasive alien species predicted to arrive, establish and have human health and/or economic impacts within Cyprus, across five thematic groups; plant species (terrestrial and freshwater), freshwater animals (fish and invertebrates), terrestrial invertebrates, terrestrial vertebrates and marine species (primary producers, invertebrates and vertebrates). CBD Level I pathways are given first, followed by CBD Level II pathways. Where an IAS had both human health and economic impacts, the pathway information was only given once. Release in naure (Release): EC, Erosion control; $H$, Hunting, R, Release in nature for use (other than above). Escape from confinement (Escape): Ag, Agriculture (including Biofuel feedstocks); Aq, Aquaculture; BZA, Botanical garden/zoo/aquaria; Pet, Pet/aquarium/terrarium species; For, Forestry; Hort, Horticulture; Orn, Ornamental purpose other than horticulture; Res, Research and ex situ breeding (in facilities); Other Escape, Other escape from confinement. Transport - contaminant (Transport - cont): CNM, Contaminant nursery material; Bait, Contaminated bait; Food, Food contaminant; Con Plant, Contaminant on plants; Seed, Seed contaminant; TT, Timber Trade; THM, Transportation of habitat material. Transport - stowaway (Transport - stow): Ang, Angling/fishing equipment; Container, Container/bulk; Air, Hitchhikers on airplane; Ship, Hitchhikers on a ship/boat; Mach, machinery/equipment; Lug, People and their luggage/equipment; Ballast, Ship/boat ballast water; Hull, Ship/boat hull fouling; Veh, Vehicles; Other Transport, Other means of transport. Corridor (Corr): Water, Interconnected waterways. Unaided (Un): Nat, Natural dispersal across borders of invasive alien species that have been introduced.

consequently raising awareness for these pathways would be valuable. We recommend developing collaborative campaigns with key industry partners, such as horticultural organizations, to increase biosecurity awareness around ornamental plants and seed contaminants, applying the European Code of Conduct on Horticulture and IAS (EPPO, 2009). The European Code of Conduct, aimed toward the tourism and industry sectors, gives five recommendations for reducing the risk of IAS arrival (Scalera, 2017).

\section{Aedes aegypti Yellow Fever Mosquito, Ae. albopictus Asian Tiger Mosquito, Ae. flavopictus, Ae. japonicus Asian Bush Mosquito and Culex quinquefasciatus Southern House Mosquito}

Five mosquito IAS were included within the top 20 lists of IAS with the potential to adversely affect human health and economies. Aedes aegypti is native to Asia, Ae. albopictus is native to south east Asia, Ae. flavopictus is native to north east Asia, Ae. japonicus native to eastern Asia. Culex quinquefasciatus has uncertain origins with both Africa and Asia being possible (Fonseca et al., 2006). All these mosquito IAS are capable of reducing tourism through nuisance biting but, more seriously, can be vectors of human disease such as dengue, yellow fever, chikungunya, and Zika (Smith et al., 2016). These IAS were identified predominantly to arrive as hitchhikers in or on airplanes and hitchhikers in or on ships/boats, in vehicles and for the Aedes mosquitoes through contaminant on plants pathways as this species lay their eggs on plant stems e.g., Aedes albopictus and lucky bamboo Dracaena sanderiana (Hofhuis et al., 2008). On contact with water, either during transit, or on arrival at the destination, the eggs develop into larvae and ultimately hatch into adult mosquitoes. These plants are predominantly introduced to countries via nurseries. Mosquito awareness campaigns, as well as following the guidance outlined in Martinou et al. (2020) for wetland management, could focus on these pathways supported through checks and signposting at airports and ports of arrival such as those carried out in New Zealand (Young, 2003), as well as within the horticulture industry.

\section{Daktulosphaira vitifoliae Grapevine Phylloxera}

Daktulosphaira vitifoliae, a small insect in the Order Hemiptera, originally from North America, was agreed to be of highest concern from the perspective of economic impacts in the context of Cyprus, and is regulated in Plant Health Regulation (EE) $2016 / 2031$. Cyprus is one of the few countries that uses traditional European vine root stock for growing grapes (Myrianthousis, 1980), whereas in most parts of Europe, due to the presence 


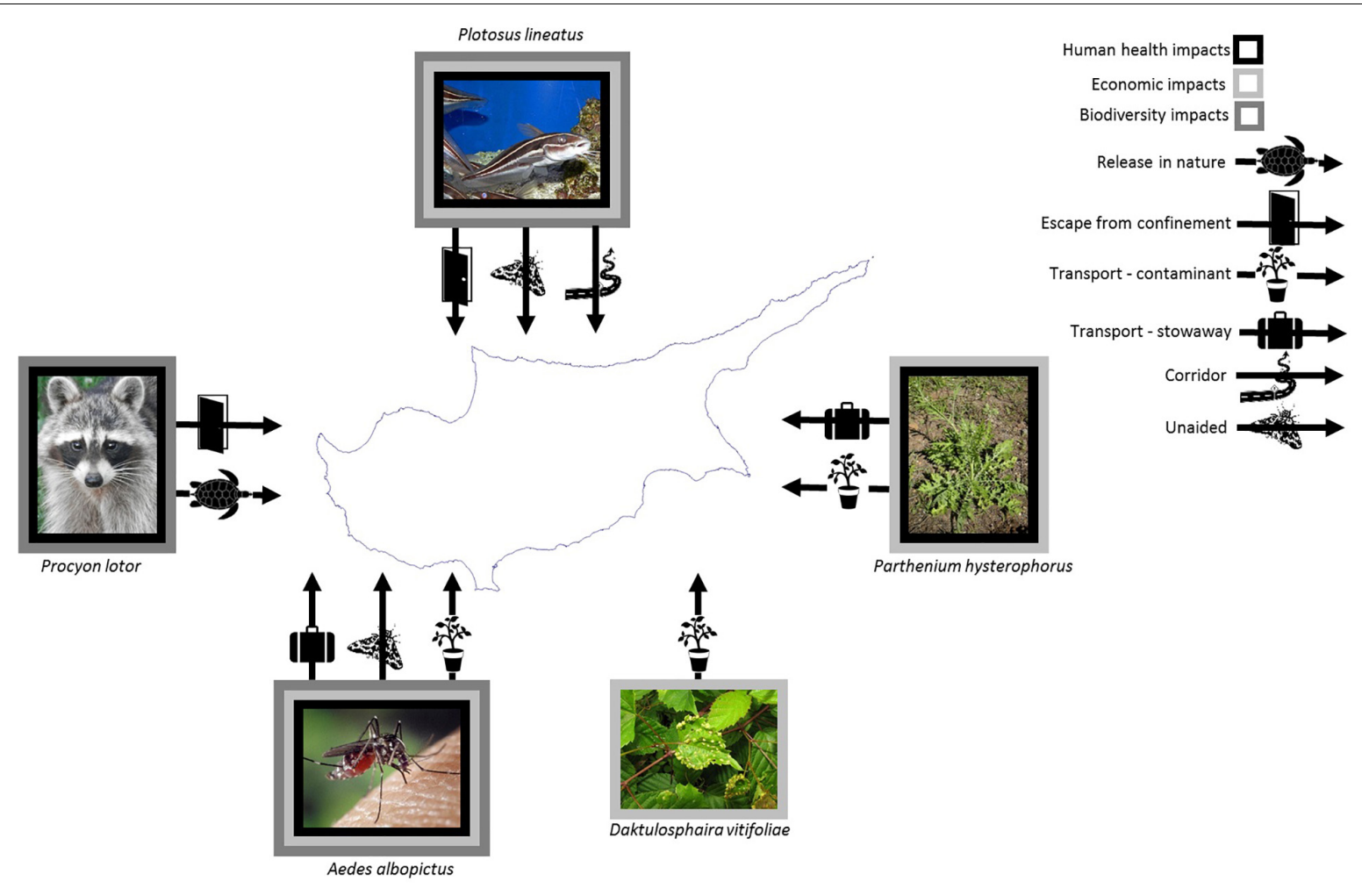

FIGURE 4 | Examples of invasive alien species considered likely to arrive, establish and adversely affect human health (black border) and/or economies (light gray border) within Cyprus. Species listed in Peyton et al. (2019) as having a negative impact on biodiversity and ecosystems (dark gray border) are also highlighted. Procyon lotor and Plotosus lineatus were listed within the top twenty of the biodiversity and ecosystem list. Aedes albopictus was scored but unranked in the biodiversity and ecosystem list. The CBD Level I pathways of introduction considered to be of importance for these representative species are depicted by symbols on arrows; Release in nature, Escape from confinement, Transport - contaminant, Transport - Stowaway, Corridor and Unaided (Convention on Biological Diversity [CBD], 2014, Harrower et al., 2018). Image credits: Map of Cyprus: @d-maps.com accessed on 23/05/2020 from https://d-maps.com/pays.php?num_pay= 187\&lang=en. Aedes albopictus: (C CDC - This media comes from the Centers for Disease Control and Prevention's Public Health Image Library (PHIL). Contributor: James Gathany. Procyon lotor: Racoon @ C Ryan Hodnett (https://commons.wikimedia.org/wiki/File:Common_Raccoon_(Procyon_lotor)_-_Guelph,_Ontario.jpg), https://creativecommons.org/licenses/by-sa/4.0/legalcode. Plotosus lineatus: Striped eel catfish @ Stan Shebs (https://commons.wikimedia.org/wiki/File: Plotosus_lineatus_1.jpg), "Plotosus lineatus 1", https://creativecommons.org/licenses/by-sa/3.0/legalcode. Parthenium hysterophorus: Whitetop weed @ Ethel Aardvark (https://commons.wikimedia.org/wiki/File:Parthenium_hysterophorus_plant_with_flowers.jpg), "Parthenium hysterophorus plant with flowers", https://creativecommons.org/licenses/by/3.0/legalcode. Daktulosphaira vitifoliae: Grape phylloxera @ Beatriz Moisset (https://commons.wikimedia.org/ wiki/File:Daktulosphaira_vitifoliae.jpg), https://creativecommons.org/licenses/by-sa/4.0/legalcode.

and subsequent damage caused by D. vitifoliae in the late 19th century, American root stock is used (Granett et al., 1996). If this IAS arrived into Cyprus, there would be devastating effects, both culturally and economically to the wine production of the country. As such, it was ranked number one in the list of IAS anticipated to have a negative economic impact. Alongside strict biosecurity protocols, efforts campaigning for awareness around this species should focus on Transport - contaminant pathways (such as contaminant nursery material and contaminant on plants). As with $P$. hysterophorus and for the Aedes mosquitoes, working closely with the horticultural industry, as well as with the agricultural industry, would support this objective.

\section{Procyon lotor Raccoon}

Procyon lotor is listed as an IAS of Union concern, and was included within the top 20 list of species with the potential to affect human health and within the top 50 for affecting economies. This species was also listed within the top 20 IAS to arrive, establish and impact biodiversity and ecosystem services (Peyton et al., 2019). Procyon lotor, originally from Central and North America, is found throughout Europe in the wild having escaped or been deliberately released from collections and is spreading in the Mediterranean (García et al., 2012; Mori et al., 2015; Lassnig et al., 2020). They were deliberately released for fur farming and hunting in Germany and the former USSR in the 1920s and 1930s (Aliev and Sanderson, 1966; Lutz, 1984). Procyon lotor is a versatile predator and can vector wildlife diseases and zoonosis, including rabies and raccoon roundworm Baylisascaris procyonis (Beltrán-Beck et al., 2012). Procyon lotor is an IAS identified as being traded in the pet trade. In terms of arrival to Cyprus, inclusion in the IAS of Union concern, Article 7 of the EU Regulation 1143/2014 means that restrictions for import, movement and trade have been in place since being listed in 2016 . It is worth noting that, although trading the IAS is illegal, private owners who kept $P$. lotor as a companion animal before it was added as an IAS of Union concern are allowed to keep them 
under confinement. A risk of unintentional escape or intentional release is still possible, however, from private keepers or zoos, and such a case was documented before 2016 in the Akrotiri area in Cyprus and the animal was removed from the wild by the Game and Fauna Service. As such, P. lotor is predicted as most likely to arrive as an escape from confinement through the botanical garden/zoos and aquaria (excluding domestic aquaria), the pet/aquarium/terrarium species (including live food for such species) and other escape from confinement pathways. Campaigns co-designed with the pet trade would support reducing the risk of escape or release.

\section{Plotosus lineatus Striped Eel Catfish}

Plotosus lineatus, native in the Red Sea, was identified as having the potential to impact both human health and economies; notably it had also previously been identified as a potential threat to biodiversity and ecosystems. Plotosus lineatus produces a venomous hemolytic neurotoxin and can cause serious injury associated with infections and severe clinical manifestations as well as impacting economies through tourism and fisheries declines. It has been found along the Israel (Golani, 2002; Galil, 2007) and Turkish coasts (Doğdu et al., 2016) and is considered to be one of the 100 "Worst Invasives" in the Mediterranean sea (Streftaris and Zenetos, 2006). This IAS entered the Mediterranean through the Lessepsian migration route via the Suez Canal, a major source of many of the invasive alien marine species in the Mediterranean. A full risk assessment of the species (Galanidi et al., 2019) led to its inclusion in the list of IAS of Union concern (EU, 2014). This IAS was predicted to arrive in Cyprus marine area through natural dispersal, through interconnected waterways/seas/basins, pet/aquarium/terrarium species (including live food for such species) and research and ex situ breeding (in facilities). As with $P$. lotor, inclusion on the IAS of Union concern means that this species is banned from being placed in the market, transported, kept or bred in contained holdings but can be kept for its natural life in the domestic environment if already purchased. In addition, this species could be kept within laboratories within the EU for research. A permit would be required under Article 8 of the EU Regulation 1143/2014 for research purposes. Escape from confinement through both these pathways are considered possible and hence included. With the exception of northern brown shrimp Penaeus aztecus, all marine IAS identified were of Indo-Pacific origin which are predicted to arrive through the pathway Corridor (Convention on Biological Diversity, 2014; Harrower et al., 2018), which in the case of the Mediterranean refers to the Suez Canal. The Suez Canal, just under 400 nautical miles south of Cyprus, provides a gateway for major shipping routes to the Red Sea, with over 18,000 vessels carrying more than $980 \mathrm{M}$ tons of cargo through the canal annually (Suez Canal Authority, 2020). The creation and subsequent widening of the Suez Canal has resulted in the increasing transfer of marine species between the Red Sea and the Mediterranean Sea, with large ecological and economic impacts and there have been calls to use the brine output from planned desalination plants along the canal to create an effective salinity barrier to halt these invasions (Galil et al., 2017).
There are many challenges associated with managing established IAS in the marine environment (Russell et al., 2017). The feasibility of eradicating marine IAS is generally low (Booy et al., 2017), therefore early reporting of new IAS is critical to inform mitigation strategies (Zenetos et al., 2019), and public awareness and education campaigns are an important part of the management of marine IAS (Giakoumi et al., 2019).

\section{CONCLUSION}

Horizon scanning to prioritize species with the potential to have negative impacts on human health or economies is an important first step in IAS decision-making and will be invaluable in informing targeted surveillance and enabling management contingency planning (Shine et al., 2010; Caffrey et al., 2014; Roy et al., 2015). Prioritized lists of IAS not yet present within a region can support biosecurity teams in implementing surveillance for early warning systems (Reaser et al., 2020) at borders, such as ports and airports, and at key hubs, such as garden centers and pet shops. Such lists are also useful for developing action plans to tackle important pathways of introduction and spread, a key component of which is the drafting of targeted communication and awareness campaigns for the public. It is critical that risk communication is developed collaboratively to ensure maximum engagement from relevant stakeholders and communities. Collaborations among all stakeholders, ensuring shared goals and understanding between citizen scientists, policy makers and researchers, is critical to informing the development of IAS decision support tools and ultimately supporting the management of biological invasions (Vanderhoeven et al., 2015; Groom et al., 2019).

\section{${ }^{+}$ORCID}

Jodey M. Peyton

orcid.org/0000-0002-8313-6194;

Angeliki F. Martinou

orcid.org/0000-0003-2892-8583;

Tim Adriaens

orcid.org/0000-0001-7268-4200;

Paraskevi K. Karachle

orcid.org/0000-0002-6934-1773;

Elena Tricarico

orcid.org/0000-0002-7392-0794;

Margarita Arianoutsou

orcid.org/0000-0002-6743-9240;

Sven Bacher

orcid.org/0000-0001-5147-7165;

Ioannis Bazos

orcid.org/0000-0002-8498-7505;

Giuseppe Brundu

orcid.org/0000-0003-3076-4098;

Iris Charalambidou

orcid.org/0000-0003-3154-4169;

Marika Galanidi

orcid.org/0000-0003-3648-6666; 
Louis Hadjioannou

orcid.org/0000-0001-5864-5467;

Margarita Hadjistylli

orcid.org/0000-0002-9084-173X;

Jason M. Hall-Spencer

orcid.org/0000-0002-6915-2518;

Carlos Jimenez

orcid.org/0000-0003-3413-6662;

Periklis Kleitou

orcid.org/0000-0002-9168-4721;

Demetris Kletou

orcid.org/0000-0001-6052-1607;

Oliver L. Pescott

orcid.org/0000-0002-0685-8046;

Cristina Preda

orcid.org/0000-0002-3513-7344;

Richard H. Shaw

orcid.org/0000-0003-0805-1841;

Saso Trajanovski

orcid.org/0000-0002-0682-8568;

Iakovos Tziortzis

orcid.org/0000-0002-9315-7773;

Elli Tzirkalli

orcid.org/0000-0002-7839-2150;

Ahmet Uludag

orcid.org/0000-0002-7137-2616;

Giovanni Vimercati

orcid.org/0000-0002-2419-8088;

Konstantin Zdraveski

orcid.org/0000-0002-5934-4292;

Argyro Zenetos

orcid.org/0000-0003-2670-042X;

Helen E. Roy

orcid.org/0000-0001-6050-679X

\section{DATA AVAILABILITY STATEMENT}

The original contributions presented in the study are included in the article/Supplementary Material, further inquiries can be directed to the corresponding author.

\section{REFERENCES}

Aliev, F. F., and Sanderson, G. C. (1966). Distribution and status of the raccoon in the Soviet Union. J. Wildlife Manag. 30, 497-502. doi: 10.2307/379 8740

Bacher, S., Blackburn, T. M., Essl, F., Genovesi, P., Heikkilä, J., Jeschke, J. M., et al. (2018). Socio-economic impact classification of alien taxa (SEICAT). Methods Ecol. Evol. 9, 159-168. doi: 10.1111/2041-210x.12844

Beltrán-Beck, B., García, F. J., and Gortázar, C. (2012). Raccoons in Europe: disease hazards due to the establishment of an invasive species. Eur. J. Wildlife Res. 58, 5-15. doi: 10.1007/s10344-011-0600-4

Booy, O., Mill, A. C., Roy, H. E., Hiley, A., Moore, N., Robertson, P., et al. (2017). Risk management to prioritise the eradication of new and emerging invasive non-native species. Biol. Invasions 19, 2401-2417. doi: 10.1007/s10530-0171451-z

Bosso, L., Di Febbraro, M., Cristinzio, G., Zoina, A., and Russo, D. (2016). Shedding light on the effects of climate change on the potential distribution of Xylella

\section{AUTHOR CONTRIBUTIONS}

HR, JP, and AM conceived the idea for this extension to the horizon scanning approach including economic impacts alongside human health impacts. HR, JP, AM, TA, NC, PK, ETr, and WR contributed to refining the study design. TA, NC, PK, AM, JP, ETr, and WR led the thematic groups. All the authors contributed to the compilation of information and the expert elicitation workshop, reviewed and approved the submitted version. JP, SR, and HR led the database development and produced the summary statistics. JP and HR led the drafting of the manuscript.

\section{FUNDING}

This work was funded by the Defra Darwin Initiative Plus (reference DarwinPlus088 Addressing drivers of change in Lake Akrotiri, Cyprus) and supported through the Natural Environment Research Council award number NE/R016429/1 as part of the UK-SCAPE programme delivering National Capability.

\section{ACKNOWLEDGMENTS}

We would like to thank the Defra Darwin Initiative Plus and NERC UK-SCAPE Programme. We would also like to thank the Akrotiri Environmental Education Centre for their ongoing support and for hosting this workshop. The plant team would also like to thank Ralf Hand for his provision of the Flora of Cyprus, which proved an invaluable tool in working through the plant lists. Finally, we thank the reviewers and the journal editor for the very useful comments they provided.

\section{SUPPLEMENTARY MATERIAL}

The Supplementary Material for this article can be found online at: https://www.frontiersin.org/articles/10.3389/fevo.2020. 566281/full\#supplementary-material

fastidiosa in the Mediterranean basin. Biol. Invasions 18, 1759-1768. doi: 10. 1007/s10530-016-1118-1

Caffrey, J. M., Baars, J.-R., Barbour, J. H., Boets, P., Boon, P., Davenport, K., et al. (2014). Tackling invasive alien species in Europe: the top 20 issues. Manag. Biol. Invasions 5, 1-20. doi: 10.1007/978-94-0159956-6_1

Carboneras, C., Genovesi, P., Vilà, M., Blackburn, T. M., Carrete, M., Clavero, M., et al. (2018). A prioritised list of invasive alien species to assist the effective implementation of EU legislation. J. Appl. Ecol. 55, 539-547. doi: 10.1111/13652664.12997

Carlton, J. T. (1996). Biological invasions and cryptogenic species. Ecology 77, 1653-1655. doi: 10.2307/2265767

Charilaou, P. (2018). Heliotropium curassavicum L.(Boraginaceae), a new alien species collected in Cyprus. Cypricola 10, 1-4.

Convention on Biological Diversity [CBD] (2014). Pathways of Introduction of Invasive Species, Their Prioritization, and Management. Montreal: CBD. 
Crowley, S. L., Hinchliffe, S., and McDonald, R. A. (2019). The parakeet protectors: understanding opposition to introduced species management. J. Environ. Manage. 229, 120-132. doi: 10.1016/j.jenvman.2017.11.036

Davis, E., Caffrey, J. M., Coughlan, N. E., Dick, J. T., and Lucy, F. E. (2018). Communications, outreach and citizen science: spreading the word about invasive alien species. Manag. Biol. Invasions 9:415. doi: 10.3391/mbi.2018.9. 4.14

Defra (2010). Check, Clean, Dry. London: Defra.

Department of Environment (2019). Invasive Alien Species Regulation: Cyprus Reporting June 1, 2019. Lefkosia: Department of Environment.

Díaz, S., Settele, J., Brondízio, E., Hien, N., Guèze, M., Agard, J., et al. (2019). Summary for Policymakers of The Global Assessment Report on Biodiversity and Ecosystem Services of the Intergovernmental Science-Policy Platform on Biodiversity and Ecosystem Services. Bonn: IPBES.

Doğdu, S. A., Uyan, A., Uygur, N., Gürlek, M., Ergüden, D., and Turan, C. (2016). First record of the Indo-Pacific striped eel catfish, Plotosus lineatus (Thunberg, 1787) from Turkish marine waters. Nat. Eng. Sci. 1, 25-32. doi: 10.28978/ nesciences. 286245

ECDC (2019). Rapid Risk Assessment: Autochthonous Cases of Dengue in Spain and France. Stockholm: European Centre for Disease Prevention and Control.

EPPO (2009). EPPO Guidelines on the Development of a Code of Conduct on Horticulture and Invasive Alien Plants, EPPO Standard PM 3/74 (1). Paris: EPPO, 263-266.

EU (2014). Regulation (EU) No 1143/2014 of the European Parliament and of the Council of 22 October 2014 on the prevention and management of the introduction and spread of invasive alien species.

Fonseca, D. M., Smith, J. L., Wilkerson, R. C., and Fleischer, R. C. (2006). Pathways of expansion and multiple introductions illustrated by large genetic differentiation among worldwide populations of the southern house mosquito. Am. J. Trop. Med. Hyg. 74, 284-289. doi: 10.4269/ajtmh.2006.74.284

Galanidi, M., Turan, C., Oztürk, B., and Zenetos, A. (2019). Europen Union (EU) risk assessment of Plotosus lineatus (Thunberg, 1787); a summary and information update. J. Black Sea/Mediterranean Environment 25, 210-231.

Galil, B., Marchini, A., Occhipinti-Ambrogi, A., and Ojaveer, H. (2017). The enlargement of the Suez Canal-Erythraean introductions and management challenges. Manag. Biol. Invasions 8, 141-152. doi: 10.3391/mbi.2017.8.2.02

Galil, B. S. (2007). Seeing red: alien species along the Mediterranean coast of Israel. Aquat. Invasions 2, 281-312. doi: 10.3391/ai.2007.2.4.2

García, J. T., García, F. J., Alda, F., González, J. L., Aramburu, M. J., Cortés, Y., et al. (2012). Recent invasion and status of the raccoon (Procyon lotor) in Spain. Biol. Invasions 14, 1305-1310. doi: 10.1007/s10530-011-0157- $\mathrm{x}$

Giakoumi, S., Katsanevakis, S., Albano, P. G., Azzurro, E., Cardoso, A. C., Cebrian, E., et al. (2019). Management priorities for marine invasive species. Sci. Total Environ. 688, 976-982. doi: 10.1016/j.scitotenv.2019.06.282

Golani, D. (2002). The indo-pacific striped eel catfish, Plotosus lineatus (Thunberg, 1787),(Osteichtyes: Siluriformes), a new record from the Mediterranean. Sci. Mar. 66, 321-323. doi: 10.3989/scimar.2002.66n3321

Granett, J., Walker, A., De Benedictis, J., Fong, G., Lin, H., and Weber, E. (1996). California grape phylloxera more variable than expected. Calif. Agric. 50, 9-13. doi: 10.3733/ca.v050n04p9

Groom, Q., Strubbe, D., Adriaens, T., Davis, A. J., Desmet, P., Oldoni, D., et al. (2019). Empowering citizens to inform decision-making as a way forward to support invasive alien species policy. Citizen Sci. Theor. Pract. 4:33. doi: 10. $5334 /$ cstp. 238

Gweta, S., Spanier, E., and Bentur, Y. (2008). Venomous fish injuries along the Israeli Mediterranean coast: scope and characterization. Israel Med. Assoc. J. 10:783.

Hadjisterkotis, E., and Heise-Pavlov, P. M. (2006). The failure of the introduction of wild boar Sus scrofa in the island of Cyprus: a case study. Eur. J. Wildlife Res. 52, 213-215. doi: 10.1007/s10344-006-0037-3

Harrower, C. A., Scalera, R., Pagad, S., Schonrogge, K., and Roy, H. E. (2018). Guidance for interpretation of CBD Categories on Introduction Pathways. Brussels: European Commission.

Hine, D. W., Please, P. M., McLeod, L., and Driver, A. B. (2015). Behaviourally Effective Communications for Invasive Animals Management: A Practical Guide. Australia: Invasive Animals Cooperative Research Centre Armidale.

Hofhuis, A., Reimerink, J., Reusken, C., Scholte, E. J., Boer, A., Takken, W., et al. (2008). The hidden passenger of lucky bamboo: do imported Aedes albopictus mosquitoes cause dengue virus transmission in the Netherlands? Vector Borne Zoonotic Dis. 9, 217-220. doi: 10.1089/vbz.2008.0071

Hulme, P. E., Bacher, S., Kenis, M., Klotz, S., Kuhn, I., Minchin, D., et al. (2008). Grasping at the routes of biological invasions: a framework for integrating pathways into policy. J. Appl. Ecol. 45, 403-414. doi: 10.1111/j.1365-2664.2007. 01442.x

ISSG (2010). Parthenium Hysterophorus (herb). Brussels: Invasive Species Specialist Group.

Kettunen, M., Genovesi, P., Gollasch, S., Pagad, S., Starfinger, U., ten Brink, P., et al. (2009). Technical Support to EU Strategy on Invasive Alien Species (IAS). Brussels: Institute for European Environmental Policy (IEEP).

Key, G., and Moore, N. (2019). Tackling invasive non-native species in the UK Overseas Territories. Island Invasives: Scaling up to Meet the Challenge, 637. IUCN

Lakshmi, C., and Srinivas, C. R. (2007). Parthenium: a wide angle view. Indian J. Dermatol. Venereol. Leprol. 73, 296-306. doi: 10.4103/0378-6323.35732

Lassnig, N., Colomar, V., Picó, G., Perelló, E., Febrer-Serra, M., Truyols-Henares, F., et al. (2020). Assessment of the invasion process of the common raccoon Procyon lotor (Carnivora: Procyonidae) on a Mediterranean island a decade after its introduction. Sci. Total Environ. 699:134191. doi: 10.1016/j.scitotenv. 2019.134191

Lazzaro, L., Essl, F., Lugliè, A., Padedda, B. M., Pyšek, P., and Brundu, G. (2018). Invasive alien plant impacts on human health and well-being. Invasive Spec. Hum. Health 2, 16-33. doi: 10.1079/9781786390981.0016

Lutz, W. (1984). Die Verbreitung des Waschbären (Procyon lotor, Linné 1758) im mitteleuropäischen Raum. Z. Jagdwissenschaft 30, 218-228. doi: 10.1007/ bf02241407

Martinou, A. F., and Roy, H. E. (2018). From local strategy to global frameworks: effects of invasive non-native species on health and well-being.

Martinou, A. F., Schäfer, S. M., Bueno Mari, R., Angelidou, I., Erguler, K., Fawcett, J., et al. (2020). A call to arms: setting the framework for a code of practice for mosquito management in European wetlands. J. Appl. Ecol. 57, 1012-1019. doi: 10.1111/1365-2664.13631

McConnachie, A. J., Strathie, L. W., Mersie, W., Gebrehiwot, L., Zewdie, K., Abdurehim, A., et al. (2011). Current and potential geographical distribution of the invasive plant Parthenium hysterophorus (Asteraceae) in eastern and southern Africa. Weed Res. 51, 71-84. doi: 10.1111/j.1365-3180.2010.00820.x

Medlock, J. M., and Vaux, A. G. (2015). Impacts of the creation, expansion and management of English wetlands on mosquito presence and abundancedeveloping strategies for future disease mitigation. Parasites Vectors 8:142. doi: 10.1186/s13071-015-0751-3

Ministry of Energy, Commerce, Industry, and Tourism (2014). Trade Service? Trade Policy, Bilateral and Public Relations Section. Cyprus: Ministry of Energy, Commerce, Industry and Tourism.

Mori, E., Mazza, G., Menchetti, M., Panzeri, M., Gager, Y., Bertolino, S., et al. (2015). The masked invader strikes again: the conquest of Italy by the Northern raccoon. Hystrix 26, 47-51.

Moore, C. G., and Mitchell, C. J. (1997). Aedes albopictus in the United States: tenyear presence and public health implications. Emerg. Infect. Dis. 3, 329-334. doi: 10.3201/eid0303.970309

Myers, N., Mittermeier, R. A., Mittermeier, C. G., Da Fonseca, G. A., and Kent, J. (2000). Biodiversity hotspots for conservation priorities. Nature 403:853. doi: $10.1038 / 35002501$

Myrianthousis, T. S. (1980). The Vine Problem of Cyprus. Cyprus: Agricultural Research Institute, Ministry of Agriculture and Natural Resources Nicosia.

Novoa, A., Dehnen-Schmutz, K., Fried, J., and Vimercati, G. (2017). Does public awareness increase support for invasive species management? Promising evidence across taxa and landscape types. Biol.gical Invasions 19, 3691-3705. doi: $10.1007 / \mathrm{s} 10530-017-1592-0$

Patel, S. (2011). Harmful and beneficial aspects of Parthenium hysterophorus: an update. 3 Biotech 1, 1-9. doi: 10.1007/s13205-011-0007-7

Pauchard, A., Meyerson, L. A., Bacher, S., Blackburn, T. M., Brundu, G., Cadotte, M. W., et al. (2018). Biodiversity assessments: origin matters. PLoS Biol. 16:e2006686. doi: 10.1371/journal.pbio.2006686

Peyton, J., Martinou, A. F., Pescott, O. L., Demetriou, M., Adriaens, T., Arianoutsou, M., et al. (2019). Horizon scanning for invasive alien species with the potential to threaten biodiversity and human health on a Mediterranean island. Biol. Invasions 21, 2107-2125. 
Psaroulaki, A., Antoniou, M., Papaeustathiou, A., Toumazos, P., Loukaides, F., and Tselentis, Y. (2006). First detection of Rickettsia felis in Ctenocephalides felis fleas parasitizing rats in Cyprus. Am. J. Trop. Med. Hyg. 74, 120-122. doi: 10.4269/ajtmh.2006.74.120

Reaser, J. K., Burgiel, S. W., Kirkey, J., Brantley, K. A., Veatch, S. D., and BurgosRodríguez, J. (2020). The early detection of and rapid response (EDRR) to invasive species: a conceptual framework and federal capacities assessment. Biol. Invasions 22, 1-19. doi: 10.1007/s10530-019-02156-w

Rezza, G., Nicoletti, L., Angelini, R., Romi, R., Finarelli, A., Panning, M., et al. (2007). Infection with chikungunya virus in Italy: an outbreak in a temperate region. Lancet 370, 1840-1846. doi: 10.1016/s0140-6736(07)61 779-6

Riccardo, F., Venturi, G., Di Luca, M., Del Manso, M., Severini, F., Andrianou, X., et al. (2019). Secondary autochthonous outbreak of chikungunya, Southern Italy, 2017. Emerg. Infect. Dis. 25:2093. doi: 10.3201/eid2511.180949

Roiz, D., Neteler, M., Castellani, C., Arnoldi, D., and Rizzoli, A. (2011). Climatic factors driving invasion of the tiger mosquito (Aedes albopictus) into new areas of Trentino, northern Italy. PLoS One 6:e14800. doi: 10.1371/journal.pone. 0014800

Romi, R., Boccolini, D., Di Luca, M., Medlock, J. M., Schaffner, F., Severini, F., et al. (2018). The Invasive Mosquitoes of Medical Importance. Invasive Species and Human Health. Wallingford: CABI.

Roy, H. E., Adriaens, T., Aldridge, D. C., Bacher, S., Bishop, J. D. D., Blackburn, T. M., et al. (2015). Invasive Alien Species - Prioritising Prevention Efforts Through Horizon Scanning. Brussles: European Commission.

Roy, H. E., Bacher, S., Essl, F., Adriaens, T., Aldridge, D. C., Bishop, J. D. D., et al. (2019a). Developing a list of invasive alien species likely to threaten biodiversity and ecosystems in the European Union. Glob. Change Biol. 25, 1032-1048. doi: $10.1111 /$ gcb. 14527

Roy, H. E., Hesketh, H., Purse, B. V., Eilenberg, J., Santini, A., Scalera, R., et al. (2017). Alien pathogens on the horizon: opportunities for predicting their threat to wildlife. Conserv. Lett. 10, 477-484. doi: 10.1111/conl. 12297

Roy, H. E., Peyton, J., Aldridge, D. C., Bantock, T., Blackburn, T. M., Britton, R., et al. (2014). Horizon scanning for invasive alien species with the potential to threaten biodiversity in Great Britain. Glob. Change Biol. 20, 3859-3871. doi: $10.1111 / \mathrm{gcb} .12603$

Roy, H. E., Peyton, J., Pescott, O., and Rorke, S. (2019b). Prioritising Invasive Non-Native Species through Horizon Scanning on the UK Overseas Territories. Oxfordshire: Centre for Ecology \& Hydrology, Crowmarsh Gifford.

Roy, H. E., Peyton, J. M., and Booy, O. (2020). Guiding principles for utilizing social influence within expert-elicitation to inform conservation decision-making. Glob. Change Biol. 26, 3181-3184. doi: 10.1111/gcb.15062

Russell, J. C., Meyer, J.-Y., Holmes, N. D., and Pagad, S. (2017). Invasive alien species on islands: impacts, distribution, interactions and management. Environ. Conserv. 44, 359-370. doi: 10.1017/s0376892917000297

Ryan, S. J., Carlson, C. J., Mordecai, E. A., and Johnson, L. R. (2019). Global expansion and redistribution of Aedes-borne virus transmission risk with climate change. PLoS Negl. Trop. Dis. 13:e0007213. doi: 10.1371/journal.pntd. 0007213

Salata, S., Georgiadis, C., and Borowiec, L. (2017). Invasive ant species (Hymenoptera: Formicidae) of Greece and Cyprus. North West. J. Zool. 15:e171204.

Samson, R., Ningal, T. F., Tiwary, A., Grote, R., Fares, S., Saaroni, H., et al. (2017). Species-Specific Information for Enhancing Ecosystem Services. Springer: The Urban Forest, 111-144.

Saponari, M., Giampetruzzi, A., Loconsole, G., Boscia, D., and Saldarelli, P. (2019). Xylella fastidiosa in olive in Apulia: where we stand. Phytopathology 109, 175-186. doi: 10.1094/phyto-08-18-0319-fi

Scalera, R. (2017). European Code of Conduct on International Travel and Invasive Alien Species. Strasbourg: Bern Convention.

Schindler, S., Staska, B., Adam, M., Rabitsch, W., and Essl, F. (2015). Alien species and public health impacts in Europe: a literature review. NeoBiota 27:1. doi: $10.3897 /$ neobiota.27.5007

Shackleton, R. T., Adriaens, T., Brundu, G., Dehnen-Schmutz, K., Estévez, R. A., Fried, J., et al. (2019). Stakeholder engagement in the study and management of invasive alien species. J. Environ. Manage. 229, 88-101. doi: 10.1016/j.jenvman. 2018.04.044
Shine, C., Kettunen, M., Genovesi, P., Essl, F., Gollasch, S., Rabitsch, W., et al. (2010). Assessment to Support Continued Development of the EU Strategy to Combat Invasive Alien Species. Brussels: Institute for European Environmental Policy.

Smith, L. B., Kasai, S., and Scott, J. G. (2016). Pyrethroid resistance in Aedes aegypti and Aedes albopictus: important mosquito vectors of human diseases. Pesticide Biochem. Physiol. 133, 1-12. doi: 10.1016/j.pestbp.2016.03.005

Sparrow, D. J., and John, E. (2016). An Introduction to the wildlife of Cyprus. Limassol: Terra Cypria.

Spitale, D., and Papatheodoulou, A. (2019). First record of the invasive Tradescantia fluminensis Vell.(Commelinaceae) in three rivers in Cyprus. Cypricola 11, 1-7. doi: 10.1111/j.1095-8339.1925.tb02005.x

Statistical Service of the Republic of Cyprus (2019). Latest Figures: Revenue from Tourism, Sep 2019. Limassol: Republic of Cyprus.

Stoett, P., Roy, H. E., and Pauchard, A. (2019). Invasive alien species and planetary and global health policy. Lancet Planet. Health 3, e400-e401. doi: 10.1016/ S2542-5196(19)30194-9

Streftaris, N., and Zenetos, A. (2006). Alien marine species in the Mediterraneanthe 100 'Worst Invasives' and their impact. Mediterranean Mar. Sci. 7, 87-118. doi: $10.12681 / \mathrm{mms} .180$

Succo, T., Leparc-Goffart, I., Ferré, J.-B., Roiz, D., Broche, B., Maquart, M., et al. (2016). Autochthonous dengue outbreak in Nîmes, south of France, July to September 2015. Eurosurveillance 21:30240. doi: 10.2807/1560-7917.ES.2016. 21.21.30240

Suez Canal Authority (2020). Navigation Statistics. Ismailia: Suez Canal Authority. Sutherland, W. J., and Burgman, M. (2015). Policy advice: use experts wisely. Nat. News 526:317. doi: 10.1038/526317a

Tziortzis, I., Zogaris, S., Papatheodoulou, A., and Marrone, F. (2014). First record of the tadpole shrimp Triops cancriformis (Branchiopoda, Notostraca) in Cyprus. Limnetica 33, 341-348.

Ueda, K. (2020). iNaturalist Research-Grade Observations. Red Swamp Crayfish Procambarus clarkii. Copenhagen: GBIF.

Vanderhoeven, S., Adriaens, T., D’hondt, B., Van Gossum, H., Vandegehuchte, M., Verreycken, H., et al. (2015). A science-based approach to tackle invasive alien species in Belgium-the role of the ISEIA protocol and the Harmonia information system as decision support tools. Manag. Biol. Invasions 6, 197208.

Vilà, M., and Hulme, P. E. (2017). "Non-native species, ecosystem services, and human well-being," in Impact of Biological Invasions on Ecosystem Services, eds M. Vilà and P. E. Hulme (Cham: Springer International Publishing), 1-14.

Williams, F., Eschen, R., Harris, A., Djeddour, D., Pratt, C., Shaw, R., et al. (2010). The Economic Cost of Invasive Non-Native Species on Great Britain. CABI Proj No VM10066. Wallingford: CABI, 1-99.

Young, N. M. J. (2003). Protect New Zealand. Australia: Biosecurity Council.

Zenetos, A., Gratsia, E., Cardoso, A. C., and Tsiamis, K. (2019). Time lags in reporting of biological invasions: the case of Mediterranean Sea. Mediterranean Mar. Sci. 20, 469-475. doi: 10.12681/mms.20716

Conflict of Interest: PK and DK were employed by the company Marine and Environmental Research (MER) Lab Ltd., MG was employed by the company Ustun Energy Engineering LLC, and AP was employed by the company I.A.CO Environmental \& Water Consultants.

The remaining authors declare that the research was conducted in the absence of any commercial or financial relationships that could be construed as a potential conflict of interest.

Copyright (C) 2020 Peyton, Martinou, Adriaens, Chartosia, Karachle, Rabitsch, Tricarico, Arianoutsou, Bacher, Bazos, Brundu, Bruno-McClung, Charalambidou, Demetriou, Galanidi, Galil, Guillem, Hadjiafxentis, Hadjioannou, Hadjistylli, HallSpencer, Jimenez, Johnstone, Kleitou, Kletou, Koukkoularidou, Leontiou, Maczey, Michailidis, Mountford, Papatheodoulou, Pescott, Phanis, Preda, Rorke, Shaw, Solarz, Taylor, Trajanovski, Tziortzis, Tzirkalli, Uludag, Vimercati, Zdraveski, Zenetos and Roy. This is an open-access article distributed under the terms of the Creative Commons Attribution License (CC BY). The use, distribution or reproduction in other forums is permitted, provided the original author(s) and the copyright owner(s) are credited and that the original publication in this journal is cited, in accordance with accepted academic practice. No use, distribution or reproduction is permitted which does not comply with these terms. 